\title{
How grassland management methods affect spider diversity
}

\author{
Tünde SZMATONA-TÚRI, ${ }^{1}$ Diána VONA-TÚRI, ${ }^{2}$ \\ László URBÁN, ${ }^{3}$ András WEIPERTH, ${ }^{4}$ Gábor MAGOS ${ }^{5}$ \\ ${ }^{1}$ AM ASzK - Forestry, Agricultural and Game Management Training School \\ and Student Hostel of Mátra, e-mail: turitunde79@gmail.com \\ ${ }^{2}$ Eötvös József Reformed Education Centre, e-mail: turidiana79@gmail.com \\ ${ }^{3}$ Bükk National Park Directorate, e-mail: urbanl@bnpi.hu \\ ${ }^{4}$ Szent István University, Faculty of Agricultural and Environmental, \\ Department of Aquaculture, e-mail: weiperth@gmail.com \\ ${ }^{5}$ Bükk National Park Directorate, e-mail: magosg@bnpi.hu
}

Manuscript received February 21, 2019; revised March 25, 2019; Accepted March 30, 2019

\begin{abstract}
The main objective of this paper is to report the effect of shrub removal, mowing, and grazing as grassland management methods on spider diversity. Sampling was conducted in the Mátra Mountains and four disturbed main road verges in Hungary. Shrub removal and mowing positively affected diversity. Moderate grazing caused increasing diversity, but intensive grazing reduced spider diversity. The intensity of mowing maintenance had various effects on diversity depending on the landscape impact. It is worth reducing the intensity of the application of mosaic treatments and considering the long-term maintenance of edge habitats in these areas.
\end{abstract}

Keywords: mowing, shrub removal, grazing, Mátra Mountains, main road verges

\section{Introduction}

Grasslands are valuable and endangered habitats across the world. From a nature conservational point of view, natural and extensive meadows are the most important, which are - due to their species composition - substantial in the maintenance of biodiversity [1]. The number of these habitats declined in the last decades [2], which is due to the expansion of the economic infrastructure and the fragmentation of grasslands or the disappearance of pasture management. The 
traditional grassland and pasture management has resulted in the appearance of valuable species, which have disappeared after the termination of management. Grassland management reduces the vegetation succession, creating mosaic habitats [3]. The aims of the treatments are to replace the traditional grassland and pasture management and thereby to preserve protected animal and plant species and maintain meadows as habitats.

Spiders have various life strategies and different habitat preferences due to their species richness. Thereby, they are considered to be ecological indicator organisms [4]: the composition of spider assemblages indicates the quality of the habitats. Various treatments, such as grazing and mowing, have a positive effect on plant diversity, creating diverse habitats where the number of species and the abundance of spiders increase [5].

The aim of our research was to investigate the effects of shrub removal, mowing and grazing intensity on the ground-dwelling spider diversity in Natura 2000 habitats of the Mátra Mountains as well as the effect of maintenance mowing intensity on roadside verges. Firstly, we examined what changes took place regarding the diversity of ground-dwelling spider assemblages after shrub removal, what differences are there between the spider assemblages of treated shrubs and of control habitats (Project 1), and how mowing affects the diversity of ground-dwelling spider species (Project 2). Moreover, we studied the optimal grazing intensity for ground-dwelling spiders in hay meadows and shrubs (Project 3 ). Finally, we assessed the effect of maintenance mowing on ground-dwelling species inhabiting Hungarian roadside verges. During assessment, we also considered the effects of vegetation structure and the naturalness status of habitats (Project 4).

\section{Materials and methods}

During our study, we used the results of four projects to examine the spider assemblages. Data collection was carried out in two parts of Hungary: the Mátra Mountains, situated in north-eastern Hungary, and four roadside verges in Central Hungary.

\section{Project 1 for the effect of shrub removal}

Four sites (1. Sár Hill Nature Reserve, 2. Gyöngyössolymos, 3. Fallóskút, 4. Parád) (Fig. 1) were selected in the Mátra Mountains between 2012 and 2015, and all sites contained a shrub, a treated shrub, and a hay meadow to research shrub removal. Two mountain sites were situated in the southern part of Mátra, 
and two in the high-altitude parts of Mátra (Table 1). Five Barber traps were set at a distance of 4-5 $\mathrm{m}$ along a transect and $10 \mathrm{~m}$ from the edge. The traps were placed twice (May-July, September-November) over a six-week period each year. Traps were emptied fortnightly [6].

\section{Project 2 for the effect of moderate mowing}

Data collection was done on three sites (1. Sár Hill Nature Reserve, 3. Fallóskút, 5. Bátonyterenye-Fallóskút) in the Mátra Mountains (Fig. 1). Two habitats were selected in all sites representing a hay meadow (mowed once a year) and a non-mowed meadow (Table 1). Live traps were established on the habitats between 2010 and 2012 due to the protected nature of this area and in order to save the protected species in these habitats. Twelve traps were set at random. The traps were placed three times (April-May, July-August, September-October) over a three-week period each year [7].

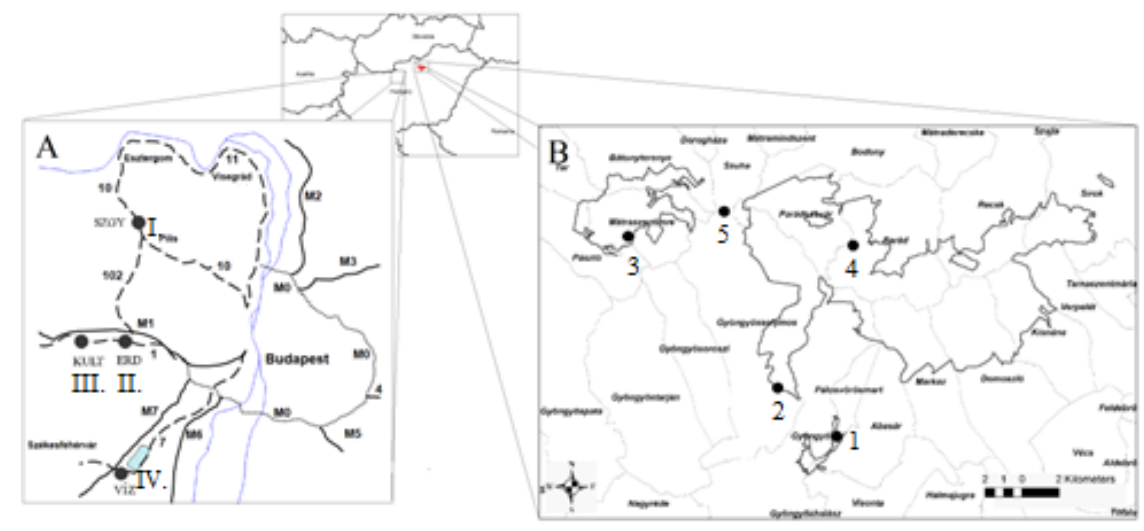

Figure 1. Sampling sites along roadsides (A) and in the Mátra Mountains (B) (for the number of sampling sites, see the Material and methods chapter)

Project 3 for the effect of grazing intensity

Data collection was done on the Somhegy-Bükk pasture (4) in the Mátra Mountains in 2014 (before grazing), 2015 (moderate grazing), and 2016 (intensive grazing). The reconstruction of habitats occurred by grazing (40 Hungarian Racka sheep and 20 Hungarian cattle). Two habitats were selected based on the mountain habitat attributes, representing grazing meadow and grazing shrub (Table 1). Five Barber traps were set at a distance of 4-5 $\mathrm{m}$ along a transect and $10 \mathrm{~m}$ from the edge. The traps were placed twice (May-July, 
September-November) over a six-week period each year. The annual data were compared against values of average temperature, and the average rainfall data of the Parádi-Recski Basin were requested from the National Meteorological Institute. Ascertainment of grazing intensity was on the basis of vegetation height, time of grazing, and number of grazing animals [8].

Table 1. Sampling sites of the Mátra Mountains

\begin{tabular}{|c|c|c|c|c|}
\hline $\mathbf{P}$ & $\mathbf{L}$ & $\mathbf{T}$ & $\mathbf{S}$ & Ve \\
\hline \multirow{3}{*}{$\begin{array}{l}\text { PA, } \\
\text { SPA }\end{array}$} & \multirow{3}{*}{ GyS } & \multirow{3}{*}{ SR } & Control meadow & Campanulo-Stipetum tirsae \\
\hline & & & Control shrub & Pruno spinosae-Crataegetum \\
\hline & & & Treated shrub & Campanulo-Stipetum tirsae \\
\hline \multirow{4}{*}{$\begin{array}{l}\text { PA, } \\
\text { SAC }\end{array}$} & \multirow{4}{*}{ SH } & \multirow[t]{2}{*}{ SR } & Treated shrub & $\begin{array}{l}\text { Pulsatillo montanae- } \\
\text { Festucetum rupicolae }\end{array}$ \\
\hline & & & Control shrub & Pruno spinosae-Crataegetum \\
\hline & & $\mathrm{SR} / \mathrm{M}$ & Control meadow & $\begin{array}{l}\text { Trifolio montanae- } \\
\text { Danthonietum alpinae }\end{array}$ \\
\hline & & M & Control meadow & $\begin{array}{l}\text { Pulsatillo montanae- } \\
\text { Festucetum rupicolae - } \\
\text { Pruno spinosae-Crataegetum }\end{array}$ \\
\hline \multirow{5}{*}{$\begin{array}{l}\text { PA, } \\
\text { SPA }\end{array}$} & \multirow{5}{*}{ FK } & \multirow{3}{*}{ M } & Mowed meadow & Anthyllido-Festucetum rubrae \\
\hline & & & Control meadow & Anthyllido-Festucetum rubrae \\
\hline & & & Mowed meadow & Anthyllido-Festucetum rubrae \\
\hline & & \multirow[t]{2}{*}{ SR } & Control shrub & $\begin{array}{l}\text { Pruno spinosae-Crataegetum } \\
\text { (Quercus ceris, Carpinus betulus) }\end{array}$ \\
\hline & & & Treated shrub & Pastinaco-Arrhenatheretum \\
\hline \multirow{2}{*}{$\begin{array}{l}\text { PA, } \\
\text { SPA }\end{array}$} & \multirow[t]{2}{*}{ B-FK } & \multirow[t]{2}{*}{ M } & Control meadow & $\begin{array}{l}\text { Anthyllido-Festucetum rubrae and } \\
\text { Alopecuro-Arrhenatheretum }\end{array}$ \\
\hline & & & Mowed meadow & Anthyllido-Festucetum rubrae \\
\hline \multirow{3}{*}{$\begin{array}{l}\text { PA, } \\
\text { SPA }\end{array}$} & \multirow{3}{*}{ Parád } & SR & Treated shrub & $\begin{array}{l}\text { Pastinaco-Arrhenatheretum and } \\
\text { Pruno spinosae-Crataegetum }\end{array}$ \\
\hline & & \multirow[b]{2}{*}{$\mathrm{SR} / \mathrm{G}$} & $\begin{array}{l}\text { Mowed meadow } \\
\text { (later grazed) }\end{array}$ & $\begin{array}{l}\text { Pastinaco-Arrhenatheretum and } \\
\text { Festuco ovinae-Nardetum }\end{array}$ \\
\hline & & & $\begin{array}{l}\text { Control shrub } \\
\text { (later shrub } \\
\text { removed and } \\
\text { grazed) }\end{array}$ & Pruno spinosae-Crataegetum \\
\hline
\end{tabular}

Along the Hungarian roads, data were collected on verges besides four sampling sites representing the main types of verge habitats between 2014 and 2015 (Fig. 1). All sites (I. Pilisjászfalu, II. Herceghalom, III. Mány, IV. Agárd) 
(Table 2) included three sections representing non-mowed, normal mowed (mowed once or twice a year), and enhanced mowed (mowed three or four times a year). The distance between two sections was $100 \mathrm{~m}$. In each section, five pitfall traps were established 5 meters from each other, and they were located $1.5 \mathrm{~m}$ from the roads. Double-glass pitfall traps filled with ethylene glycol were used, which were left in the field for three weeks and three times a year in different seasons (April-May, July-August, October-November) [9].

Table 2. Characterization of main road verges

\begin{tabular}{lll}
\hline Road section & \multicolumn{1}{c}{ Location } & \multicolumn{1}{c}{ Vegetation of adjacent area } \\
\hline Pilisjászfalu (I.) & $\begin{array}{l}\text { Road number 10 } \\
\text { (Budapest-Esztergom) }\end{array}$ & $\begin{array}{l}\text { dry dolomite grassland with } \\
\text { shrubs }\end{array}$ \\
\hline Herceghalom (II.) & $\begin{array}{l}\text { Road number 1 } \\
\text { (Budapest-Györ) }\end{array}$ & $\begin{array}{l}\text { installed tree line with Robinia } \\
\text { pseudoacacia, Populus sp., Ulmus } \\
\text { minor }\end{array}$ \\
\hline Mány (III.) & $\begin{array}{l}\text { Road number 1 } \\
\text { (Budapest-Györ) } \\
\text { between two roads }\end{array}$ & arable, corn and cereal plantation \\
\hline Agárd (IV.) & $\begin{array}{l}\text { Road number 7 } \\
\text { (Budapest- } \\
\text { Székesfehérvár) }\end{array}$ & $\begin{array}{l}\text { Populus sp. plantation next to the } \\
\text { Velencei Lake. Grass height is } \\
\text { sometimes 1 meter on the verges. }\end{array}$ \\
\hline
\end{tabular}

We used the PAST Paleontological Statistics Software Package for data analyses [10]. Besides the average number of species and individuals, we also calculated Shannon diversity. For the comparison of values in the case of more samples, the one-way ANOVA whereas for the investigation of more treatments or factors the two-factor ANOVA was used.

\section{Results and discussions}

\section{Project 1}

Examining shrub removal, the median value of the number of species and individuals was higher in the year following shrub removal compared to the pretreatment values - similarly to control habitats - , but differences were significant only in treated habitats (number of species: $p=0.03$, number of individuals: $p=$ 0.01) (fig-s 2-3). Microclimate changed by shrub removal influences spider abundance [11] and could explain why average species richness and number of individuals increased directly after shrub removal. The higher abundance of rare 
and protected species in mowed habitats represents the regional differences (Table 3), but we found no significant differences between abundance values ( $\mathrm{p}$ $=0.75$ ). Based on our results, shrub removal had a positive influence on grounddwelling spider diversity.
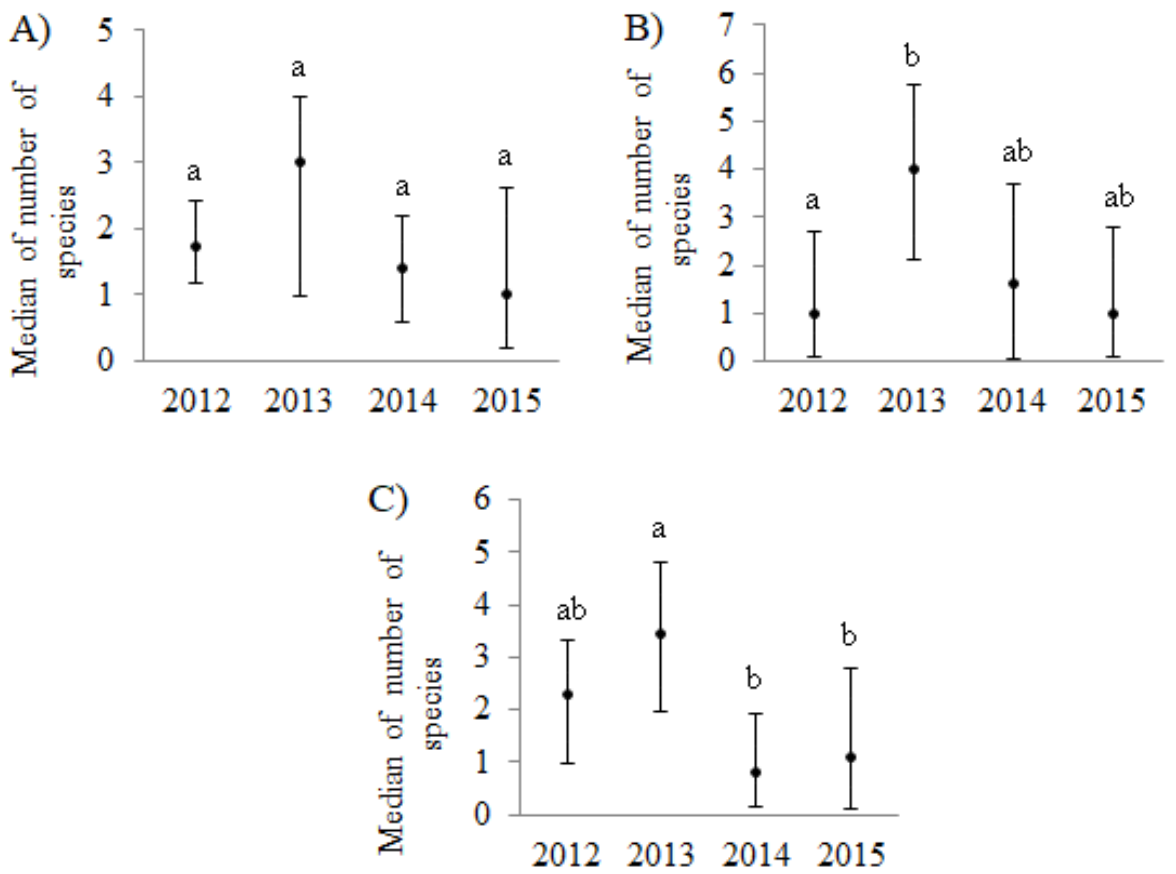

Figure 2. The median values of the number of species per traps in the case of control shrubs (A), treated shrubs (B), and control meadows (C). The different letters note the significant differences $(\mathrm{p}<0.05)$.
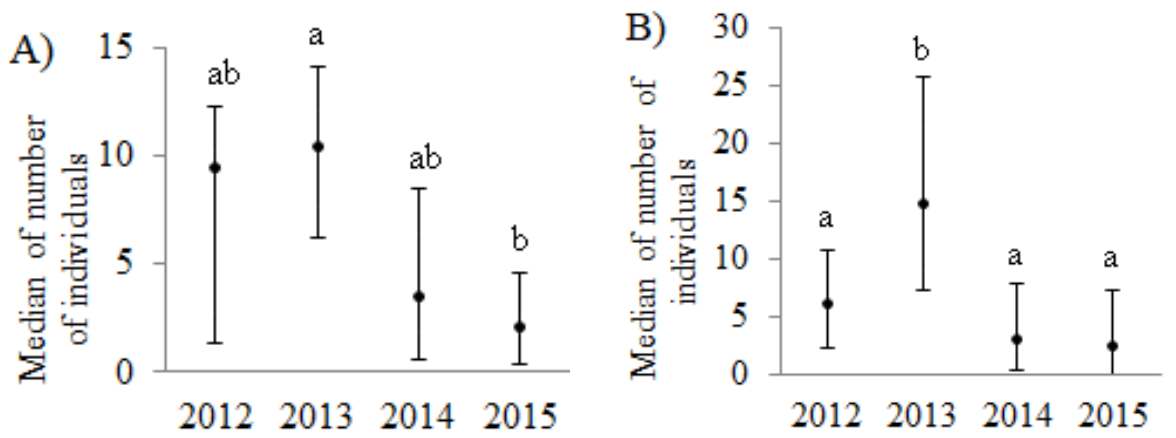


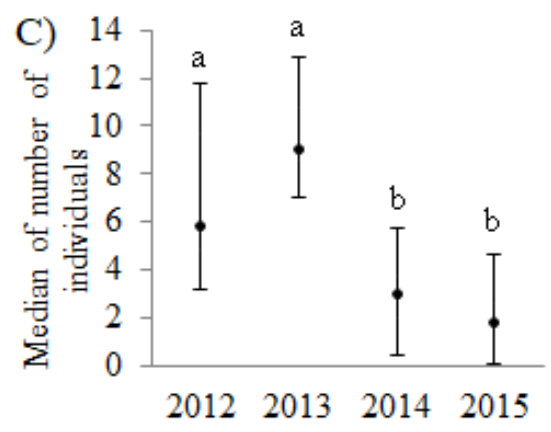

Figure 3. Median values of the number of individuals per traps in the case of control shrubs (A), treated shrubs (B), and control meadows (C). The different letters note the significant differences $(\mathrm{p}<0.05)$.

Table 3. Abundance of protected and rare spider species (Ar \%) - TS: Treated shrub, CS: Control shrub, CM: Control meadow

\begin{tabular}{|c|c|c|c|c|c|}
\hline \multirow{2}{*}{ Species } & & \multicolumn{4}{|c|}{$\operatorname{Ar}(\%)$} \\
\hline & & TS & $\mathrm{CS}$ & $\mathrm{CM}$ & Total \\
\hline \multirow{6}{*}{$\begin{array}{l}\text { Protected } \\
\text { species }\end{array}$} & $\begin{array}{l}\text { Nemesia pannonica } \\
\text { (Herman, 1879) }\end{array}$ & 0.60 & 0.10 & 1.10 & 1.90 \\
\hline & Eresus kollari & 0.01 & 0.01 & 0.03 & 0.07 \\
\hline & Rossi, 1846 & & & & \\
\hline & Atypus affinis & 0.03 & 0.09 & 0.05 & 0.19 \\
\hline & Eichwald, 1830 & & & & \\
\hline & $\begin{array}{l}\text { Geolycosa vultuosa } \\
\text { C. L. Koch, } 1838\end{array}$ & 0.01 & 0 & 0 & 0.01 \\
\hline \multirow{4}{*}{ Rare species } & $\begin{array}{l}\text { Arctosa figurata } \\
\text { (Simon, 1876) }\end{array}$ & 0 & 0 & 0.05 & 0.05 \\
\hline & $\begin{array}{l}\text { Zelotes aurantiacus } \\
\text { Miller, } 1967\end{array}$ & 0 & 0.01 & 0 & 0.01 \\
\hline & $\begin{array}{l}\text { Drassodes cupreus } \\
\text { (Blackwall, 1834) }\end{array}$ & 0.01 & 0 & 0.01 & 0 \\
\hline & $\begin{array}{l}\text { Gnaphosa modestior } \\
\text { Kulczyński, } 1897\end{array}$ & 0.10 & 0.50 & 0.20 & 0.20 \\
\hline
\end{tabular}

According to the two-way ANOVA, the differences between the diversity of treated and control habitats were significant, but between years differences were not significant (Table 4). Spider diversity was lower after shrub removal compared to pre-treatment species diversity and was higher in the second year 
after shrub removal. There was a decrease in the diversity in the final year of the study caused by the absence of additional treatments (Table 5). This is the first phase of the grassland management process and can change the coverage of vegetation [12]. It may explain why the assemblages had a relatively low diversity in the year following shrub removal, which was the highest in the second year. It was caused by the presence of neighbouring refuge habitats that supported the survival of species. The shrubs were homogeneous habitats where diversity was lower and the abundance was higher compared to the heterogeneous hay meadows, where the diversity was higher and the abundance was lower. Since additional treatments were not applied, these habitats are threatened with succession. It was presented by a reduction in species richness that was observed in the last year when shrubs appeared in grassland habitats [6].

Table 4. Results of the two-way ANOVA for the effect of shrub removal (shrubs, treated shrubs, hay meadows) on diversity in the Mátra Mountains and in the examined years (2012-2015)

\begin{tabular}{llllll}
\hline & Sum of sqrs & df & Mean square & f & \multicolumn{1}{c}{$\mathrm{p}$} \\
\hline Years & 0.27841 & 3 & 0.09280 & 1.201 & 0.3866 \\
Treatments & 1.50178 & 2 & 0.75089 & 9.71736 & 0.01313 \\
Error & 0.46363 & 6 & 0.07727 & & \\
Total & 2.24383 & 11 & & & \\
\hline
\end{tabular}

Table 5. Values of Shannon diversity in treated shrubs and control habitats during the examined years (2012: before shrub removal, 2013-2015: after shrub removal)

\begin{tabular}{lcccc}
\hline \multirow{2}{*}{ Shannon diversity } & \multicolumn{4}{c}{ Examined years } \\
\cline { 2 - 5 } & 2012 & 2013 & 2014 & 2015 \\
\cline { 2 - 5 } Control shrubs & 2.164 & 2.011 & 2.568 & 1.792 \\
Treated shrubs & 2.791 & 2.250 & 2.906 & 2.239 \\
Control meadows & 2.929 & 3.114 & 2.847 & 3.106 \\
\hline
\end{tabular}

\section{Project 2}

When examining mowing, we did not find significant differences between the examined values of spider assemblages of mowed and non-mowed meadows, but the median values of abundance and species richness (Fig. 4) and diversity (Table 6) were higher in the mowed meadows. Mowing has a positive effect on floral diversity, which increases the species richness of spiders [13]. According to the two-way ANOVA, differences between diversity of mowed and non- 
mowed meadows were not significant, but between three different sites these were significant (Table 7).
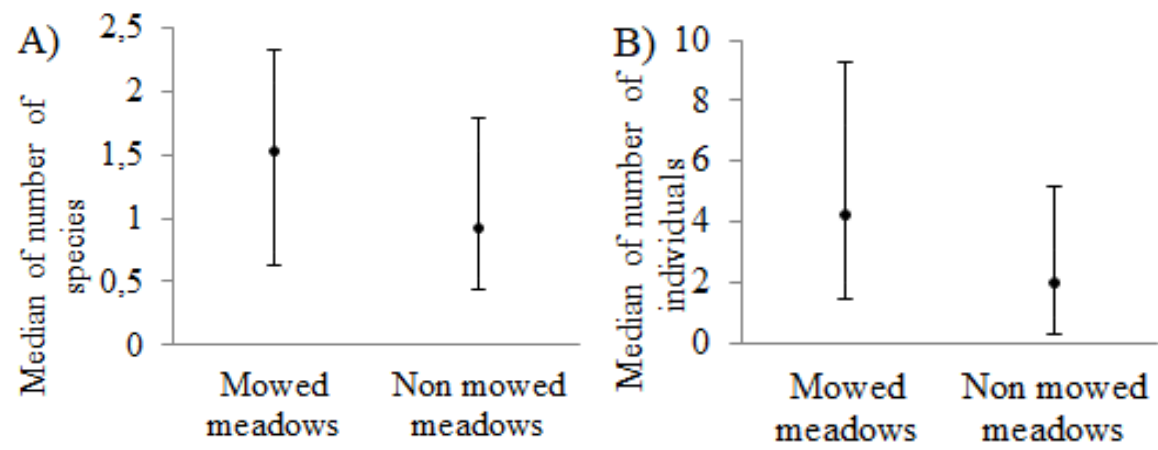

Figure 4. Median values of number of species (A) and number of individuals per traps (B) in mowed and non-mowed meadows. The differences were not significant $(\mathrm{p}>0.05)$.

During our research, hay meadows had diverse spider assemblages, which can be maintained by controlled mowing management. In hay meadows, the number of herbivore species is high due to rich vegetation. In more open habitats, the sward often includes more dicotyledonous than monocotyledonous species, thereby explaining the correlations between arthropod and flower diversity [14]. Mowing has similar direct influences compared to shrub removal. To preserve shelters and resources for many species, we applied rotational management in the meadows. The relative abundance of rare and protected species illustrates well that most such species prefer open to semi-open habitats (Table 8). Our results corroborated that hay meadow could be conserved with mowing, and thus spider and floral diversity could be maintained. Similarly to shrub removal, mowing can be considered to act as an intermediate disturbance [15]. The annual treatments can be considered as a low-intensity disturbance that produces a higher diversity of spider assemblages than in untreated habitats, where grassland and forest species occur [6].

Table 6. Values of Shannon diversity in mowed and non-mowed meadows

\begin{tabular}{lcc}
\hline \multirow{2}{*}{ Shannon diversity } & \multicolumn{2}{c}{ Treatment } \\
\cline { 2 - 3 } & Mowed meadows & Non-mowed meadows \\
\cline { 2 - 3 } Location 1 & 1.750 & 1.459 \\
Location 2 & 2.091 & 1.966 \\
Location 3 & 1.781 & 1.643 \\
\hline
\end{tabular}


Table 7. Results of ANOVA for the effect of mowing (mowed meadows and non-mowed meadows) in the Mátra Mountains and locations on diversity

\begin{tabular}{lccccc}
\hline & Sum of sqrs & df & Mean square & f & $\mathrm{p}$ \\
\hline Locations & 0.19426 & 2 & 0.09713 & 22.7572 & 0.04209 \\
Mowing & 0.05170 & 1 & 0.05170 & 12.1148 & 0.07355 \\
Error & 0.00853 & 2 & 0.00426 & & \\
Total & 0.25450 & 5 & & & \\
\hline
\end{tabular}

Table 8. Abundance of protected and rare spider species (Ar \%) - MM: Mowed meadow, NM: Non-mowed meadow

\begin{tabular}{llcc}
\hline & \multirow{2}{*}{ Species } & \multicolumn{2}{c}{ Ar (\%) } \\
& N. pannonica & 3.50 & 1.30 \\
Protected & A. piceus Sulzer, & 0.10 & 0.20 \\
species & 1776 & & \\
& E. kollari & 0.30 & 0.10 \\
& G. vultuosa & 0.10 & 0 \\
\hline Rare species & A. figurata & 0.05 & 0 \\
& D. cupreus & 0.10 & 0 \\
& G. modestior & 0 & 0.10 \\
\hline
\end{tabular}

\section{Project 3}

According to our results, there was a negative correlation between grazing intensity and spider diversity, but significant differences were not found (Table 9 ). In the case of meadows, diversity (Table 10) as well as the median value of species richness (Fig. 5A) and abundance (Fig. 6A) increased during moderate grazing despite decreasing average temperature compared to pre-treatment diversity and decreased during intensive grazing. In meadows, moderate grazing resulted in a lower vegetation height and an increased amount of sunlight reaching the ground, which positively affected grassland species.

Contrarily, spider diversity (Table 11) and the median value of species richness (Fig. 5B) and abundance in shrub (Fig. 6B) decreased during moderate and intensive grazing as well; this is inversely related to average rainfall values. Increasing diversity in shrub can be expected in the following year when colonization may take place from the neighbouring natural meadows. 

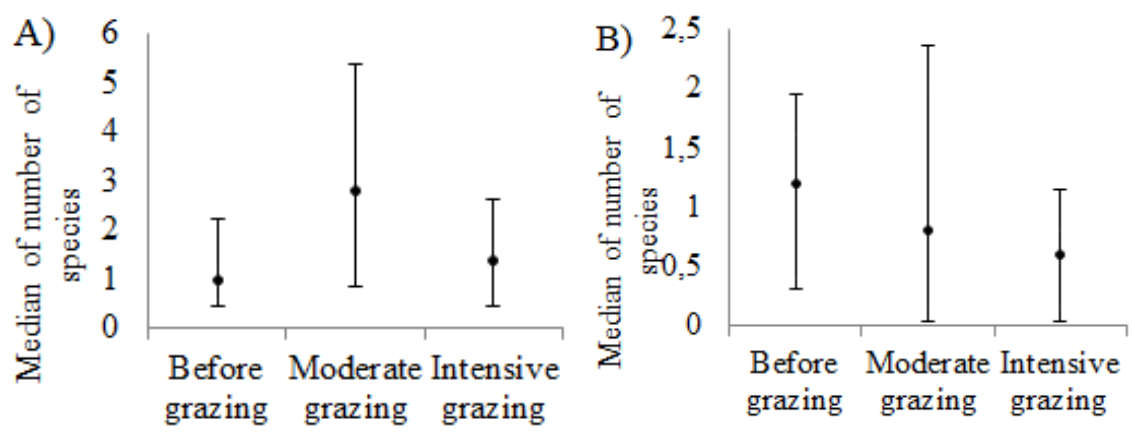

Figure 5: Median values of the number of species per traps in the case of mowed meadow (A) and shrub (B) before grazing, during moderate grazing, and during intensive grazing. The differences were not significant $(\mathrm{p}>0.05)$.
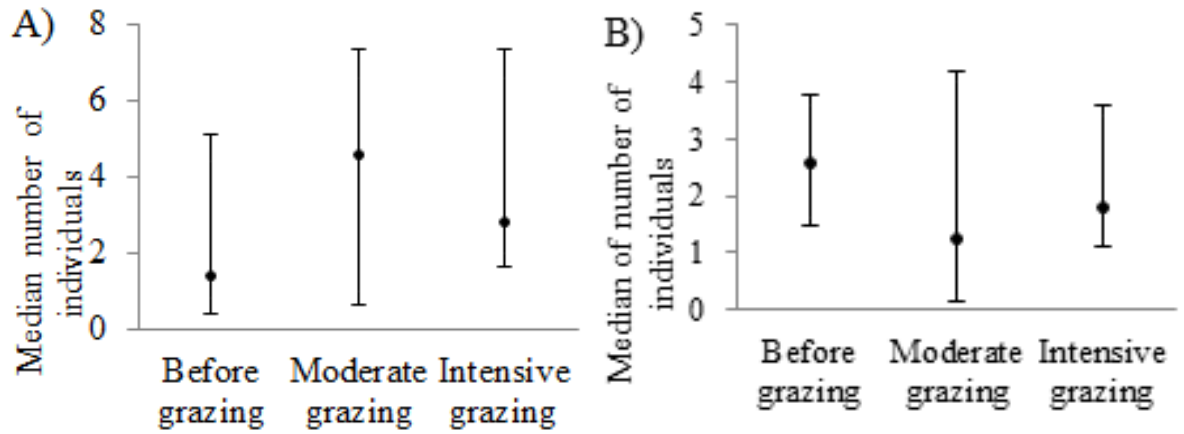

Figure 6: Median values of the number of individuals per traps in the case of mowed meadow (A) and shrub (B) before grazing, during moderate grazing, and during intensive grazing. The differences were not significant $(\mathrm{p}>0.05)$.

Table 9. Results of the two-way ANOVA for the impact of grazing intensity (examined years: 2014: before grazing, 2015: moderate grazing, 2016: intensive grazing) in the Mátra Mts. and vegetation structure (meadows and scrubs) on diversity

\begin{tabular}{llllll}
\hline & Sum of sqrs & df & Mean square & f & $\mathrm{p}$ \\
\hline $\begin{array}{l}\text { Vegetation } \\
\text { structure }\end{array}$ & 0.30165 & 1 & 0.30195 & 7.8937 & 0.106 \\
Years & 0.15823 & 2 & 0.07941 & 2.076 & 0.325 \\
Error & 0.07650 & 2 & 0.38252 & & \\
Total & 0.53728 & 5 & & & \\
\hline
\end{tabular}


Table 10. Values of Shannon diversity in grazed habitats during the examined years (2014: before grazing, 2015: during moderate grazing, 2016: during intensive grazing)

\begin{tabular}{lccc}
\hline Shannon diversity & $\begin{array}{c}\text { Before } \\
\text { grazing }\end{array}$ & $\begin{array}{c}\text { Moderate } \\
\text { grazing }\end{array}$ & $\begin{array}{c}\text { Intensive } \\
\text { grazing }\end{array}$ \\
\cline { 2 - 4 } Mowed meadow & 2.404 & 2.652 & 2.19 \\
Shrub & 2.236 & 1.931 & 1.733 \\
\hline
\end{tabular}

However, this year, besides intensive grazing, shrubs were extensively removed, causing a higher level of disturbance for spider assemblages, wherefore their diversity decreased. Based on these results, moderate grazing is an effective grassland management type to increase spider diversity on the SomhegyBükk pasture, but intensive grazing influences the assemblages negatively. Moderate grazing is regarded as intermediate disturbance [15], which causes high diversity [8].

\section{Project 4}

Based on our results, the mowed verges had diverse spider fauna similarly to semi-natural habitats [9]. As ecological corridors, these verges have homogeneous vegetation, but due to the diversity of adjacent areas these verges can provide habitats for several animals. On roadside verges, we did not find significant differences between the investigated sections (Table 11), but the highest median value of the number of species was in normal mowed sections (Fig. 7A), while the highest median value of abundance was in non-mowed sections (Fig. 7B). Our results showed that the different verge types influenced optimal maintenance intensity. In the case of forest and wet verges, the normal mowed sections were the most diverse. In contrast with this, other verges became more diverse due to enhanced maintenance (Table 12).

Table 11. Results of ANOVA for the effect of maintenance mowing (no mowing, normal mowing, enhanced mowing) and habitat types of roadside verges (dry grassland, agricultural habitat, forest, wetland)

\begin{tabular}{llllcl}
\hline & Sum of sqrs & df & Mean square & f & p \\
\hline Maintenance & 0.039835 & 2 & 0.019917 & 0.93523 & 0.443 \\
Habitat types & 1.225065 & 3 & 0.750216 & 3.52267 & 0.08857 \\
Error & 0.127781 & 6 & 0.021296 & & \\
Total & 2.392681 & 11 & & & \\
\hline
\end{tabular}



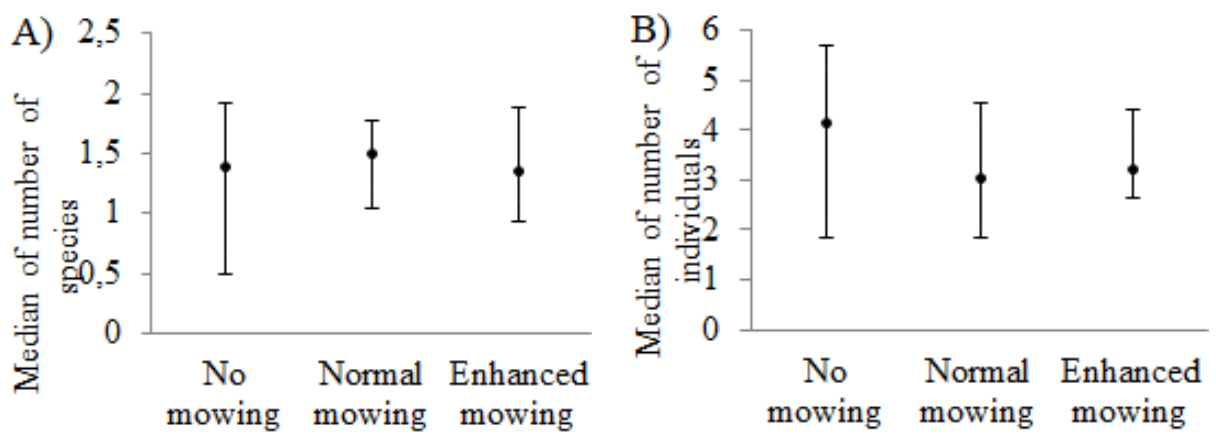

Figure 7. Median values of the number of species (A) and individuals (B) per traps in the case of no mowing, normal mowing, and enhanced mowing on roadside verges. The differences were not significant $(\mathrm{p}>0.05)$.

The results supported the intermediate disturbance hypothesis [15] in the case of wetland and forest habitats because in these verges next to shaded habitats grassland and forest species found suitable circumstances due to moderate mowing. Our results showed that the verges could provide refuges for grassland spiders influenced by suitable intensity mowing. Furthermore, in the case of disturbance-tolerant species, mowing extends to the borders of adjacent areas. Based on these results, we suggest considering the structure and naturalness of verge habitats when selecting the appropriate degree of mowing intensity.

Table 12. Values of Shannon diversity of the habitat types on main road verges by maintenance mowing (no mowing, normal mowing, enhanced mowing)

\begin{tabular}{lcccc}
\hline \multirow{2}{*}{ Shannon diversity } & \multicolumn{4}{c}{ Habitat types } \\
\cline { 2 - 5 } & $\begin{array}{c}\text { Dry } \\
\text { grassland }\end{array}$ & $\begin{array}{c}\text { Agricultural } \\
\text { habitat }\end{array}$ & Forest & Wetland \\
\cline { 2 - 5 } No mowing & 2.107 & 2.417 & 2.458 & 2.406 \\
Normal mowing & 2.261 & 2.405 & 2.729 & 2.554 \\
Enhanced mowing & 2.276 & 2.691 & 2.546 & 2.21 \\
\hline
\end{tabular}

\section{Conclusions}

We concluded that shrub removal is an effective grassland management action to increase spider diversity in Natura 2000 habitats. Consequently, shrub removal is not enough to maintain spider diversity. It is necessary to continue the grassland management process if we are to maintain diverse spider communities 
and assist the overall recovery of these valuable habitats [6]. Based on our results, we suggest the application of moderate mowing to maintain the Natura 2000 habitats for spiders [7]. It can also be concluded that moderate grazing is an optimal grassland management to maintain meadows as habitats for several spider species and preserve the high spider diversity. Moreover, when deciding on grazing intensity, it is important to consider the structure of habitats and to avoid the use of more treatments simultaneously [8]. Besides Natura 2000 habitats, the maintenance of disturbed areas is important, as well. We concluded that maintenance mowing does not have major influence on spider diversity, but it is necessary to preserve the spider species. Furthermore, the type of verge habitats has to be considered when selecting the appropriate degree of mowing intensity.

\section{Acknowledgements}

The three projects of the Mátra Mountains were funded by the Bükk National Park Directorate. We thank György Dudás for his support, Attila Kemény for sampling in the Mátra Mountains, Éva Rácz for sampling, and Blanka Gál for the selection of species along the road verges. The project along the road verges was funded by CEDR-Harmony (http://www.harmonyproject.net/). We thank the National Road Authority and the directory of the Duna-Ipoly National Park for the permissions to undertake field work. We thank the field experts for botanical and zoological reference sampling and for measuring the biotic and abiotic environmental parameters of each sampling area.

\section{References}

[1] Déri, E., Lengyel, S., Lontay, L., Deák, B., Török, P., Magura, T., Horváth, R., Kisfali, M., Ruff, G., Tóthmérész, B. (2009), Természetvédelmi stratégiák alkalmazása a Hortobágyon: az egyek-pusztakócsi LIFE-Nature program eredményei. Természetvédelemi Közlemények $15,89-102$.

[2] Bérces, S. (2011), A biodiverzitás monitorozása homoki élőhelyeken a Duna-Ipoly Nemzeti Park Igazgatóság területén. Rosalia 6, 447-471.

[3] Gerner, G., Biró, É., Bódis, J., Kun, R., Nagy, T., Molnár, Zs., Biró, M. (2015), Élőhelytípusok és tájhasználat Sztána és Zsobok határában. In: Molnár. K., Molnár., Zs. (eds.), Élet és rend a határban. Etnoökológiai Kutatótábor Kalotaszegen. Sztánai Füzetek 19. Kolozsvár-Sztána: Művelődés Egyesület-Szentimrei Alapítvány. 79-101.

[4] Blandin, P. (1986), Bioindicateurs et diagnostic des systèmes écologiques. Bulletin d'écologie 17, 215-307. 
[5] Jeanneret, Ph., Schüpbach, B., Pfiffner, L., Walter, T. (2003), Arthropod reaction to landscape and habitat features in agricultural landscapes. Landscape Ecology 18, 253-263.

[6] Szmatona-Túri, T., Vona-Túri, D., Magos, G., Urbán, L. (2017), The effect of grassland management on diversity and composition of ground-dwelling spider assemblages in the Mátra Landscape Protection Area of Hungary. Biologia 72(6), 642-651.

[7] Szmatona-Túri, T., Vona-Túri, D. (2016), The effect of grassland management on diversity of spider assemblages in the Mátra Mountain. Ecologica Monenegrina 7, 291-297.

[8] Szmatona-Túri, T., Vona-Túri, D., Urbán, L., Magos, G. (2018), The effect of grazing intensity on ground-dwelling spiders of grassy and shrubby habitats. Acta Zoologica Bulgarica 70(2), 195-202.

[9] Vona-Túri, D., Szmatona-Túri, T., Kádár, F., Kiss, B., Weiperth, A., Gál, B. (2016), Grounddwelling arthropod (Araneae, Coleoptera: Carabidae, Isopoda: Oniscidea) assemblages on Hungarian main road verges. Acta Universitatis Sapientiae Agriculture and Environment 8, 98-113.

[10] Hammer, O., Harper, D. A. T., Ryan, P. D. (2001), PAST: Paleontological statistics software package for education and data analysis. Palaeontologia Electronica 4(1).

[11] Kohyani, P. T., Bossuyt, B. Bonte, D., Hoffmann, M. (2008), Grazing as a management tool in dune grasslands: Evidence of soil and scale dependence of the effect of large herbivores on plant diversity. Biological Conservation 141, 1687-1694.

[12] Berlow, E. L., D'Antonio, C. M., Swartz, H. (2003), Response of herbs to shrub removal across natural and experimental variation in soil moisture. Ecological Applications 13, 13751387.

[13] Malumbres-Olarte, A., Vink, C. J., Ross, J. G., Ruickshank, R. H., Paterson, A. M. (2013), The role of habitat complexity on spider communities in native alpine grasslands of New Zealand. Insect Conservation and Diversity 6, 124-134.

[14] Noordijk, J., Delille, K., Schaffers, A. P., Sýkora, K.V. (2009), Optimizing grassland management for flower-visiting insects in roadside verges. Biological Conservation 142, 2097-2103.

[15] Connell, J. H. (1978), Diversity in tropical rain forests and coral reefs. Science 199, 13021310. 